\title{
Retraction Note: Stability of slope rainfall condition based on GIS and nutrition intervention of football training
}

\author{
Wang Hui ${ }^{1}$
}

Published online: 23 November 2021

C) Saudi Society for Geosciences 2021

Retraction Note: Arabian Journal of Geosciences (2021) 14: 1554

https://doi.org/10.1007/s12517-021-08011-4

The Editor-in-Chief and the Publisher have retracted this article because the content of this article is nonsensical. The peer review process was not carried out in accordance with the Publisher's peer review policy. The author has not responded to correspondence regarding this retraction.

The original article can be found online at https://doi.org/10.1007/ s12517-021-08011-4.

\section{Wang Hui}

Wh125997284@163.com

1 Xianyang Vocational and Technical College, Xi'an 712000,

Shaanxi, China 